\title{
Regeneration of Blueberry Cultivars through Indirect Shoot Organogenesis
}

\author{
Dongliang Qiu' and Xiangying Wei \\ College of Horticulture, Fujian Agriculture and Forestry University, Fuzhou, \\ Fujian Province 350002, China
}

\author{
Shufang Fan \\ Jingchu University of Technology, College of Biological Engineering and \\ Institute of Plant Germplasm Resources Exploitation and Utilization, \\ Jingmen, Hubei Province 448000, China
}

\section{Dawei Jian \\ Jingmen Forestry Bureau, Jingmen, Hubei Province 448000, China}

\section{Jianjun Chen ${ }^{1}$ \\ University of Florida, IFAS, Mid-Florida Research and Education Center, 2725 South Binion Road, Apopka, FL 32703}

Additional index words. callus, Ericaceae, micropropagation, shoot regeneration, Vaccinium, zeatin

\begin{abstract}
Leaf explants derived from in vitro-grown shoots of blueberry cultivars Bluejay, Pink Lemonade, Sunshine Blue, and Top Hat were cultured on woody plant medium (WPM) supplemented with 9.12 $\mu$ M 6-(4-hydroxy-3-methylbut-2-enylamino) purine or zeatin $(\mathrm{ZT})$ in combination with $1.23,2.46$, or $4.92 \mu \mathrm{M}$ indole-3-butyric acid (IBA). Calluses were induced from the explants and adventitious shoots were regenerated. 'Sunshine Blue' and 'Top Hat' produced more than four shoots per explant but shoot numbers were less than one for each 'Pink Lemonade' explant and about 0.2 per 'Bluejay' explant. The results indicate that there is significant difference among cultivars in indirect shoot organogenesis. The differences may be related to their diverse genetic background as they are polyploid hybrids. Microcuttings derived from adventitious shoots of 'Sunshine Blue' rooted in vitro in WPM medium supplemented with $9.84 \mu \mathrm{M}$ IBA and also rooted ex vitro in a peat-based substrate after cuttings were dipped or not dipped in IBA solutions. Direct rooting of microcuttings in the peat-based substrate was effective, suggesting that in vitro rooting may not be necessarily needed. Survival rate of ex vitro-rooted plants in a shaded greenhouse was high, more than $90 \%$. The established shoot regeneration protocols could be used for rapid propagation of 'Sunshine Blue' and 'Top Hat' and for cultivar improvement through genetic transformation.
\end{abstract}

Blueberries (Vaccinium spp.) are smallfruit crops and have become increasingly popular with consumers because of their high nutraceutical and pharmaceutical value (Basu et al., 2010; Miller and Shukitt-Hale, 2012; Vendrame et al., 2016; Whyte and Williams, 2015). There are five main groups of blueberries: 1) northern highbush ( $\mathrm{Vacci}$ nium corymbosum L.); 2) southern highbush, developed from crosses between $V$. corymbosum, Vaccinium darrowii Camp, and other blueberry species; 3) lowbush (Vaccinium angustifolium Ait., Vaccinium myrtilloides Michx., and Vaccinium boreale Hall and Aald.); 4) half-high derived from crosses between highbush and lowbush; and 5) rabbiteye (Vaccinium virgatum Ait.) (Caspersen

\footnotetext{
Received for publication 9 Mar. 2018. Accepted for publication 18 May 2018 .

This work was supported by the Fujian Fumin Foundation and New Century Talent Training Foundation of Fujian Province.

${ }^{1}$ Corresponding authors. E-mail: qiudongliang@ aliyun.com or jjchen@ufl.edu.
}

et al., 2016; Debnath, 2007). Among them, $V$. angustifolium, $V$. corymbosum, and $V$. myrtilloides are tetraploid with the chromosome number of $2 n=4 x=48$, whereas $V$. virgatum is hexaploid with $2 n=6 x=72$ (Brevis et al., 2008). The highbush blueberries are by far the most important commercial crop. Worldwide highbush blueberry production increased from 58,400 ha in 2007 to 110,800 ha in 2014 (Brazelton, 2015). North America represented more than $50 \%$ of the production area and accounted for almost $60 \%$ of the global highbush blueberry production in 2014 (Brazelton, 2015), of which Florida blueberry production acreage increased by $73 \%$ from 2007 to 2012 (USDA, 2013).

Blueberries are traditionally propagated via stem cuttings (Marino et al., 2014), but not all cultivars can be effectively propagated through this method (Lyrene, 1981). Stem cuttings are also not efficient in increasing numbers of starting materials or propagules for commercial introduction of new cultivars (Miller et al., 2004). Furthermore, stem cuttings may bring or spread pathogens (Tzanetakis et al., 2017). Recently, a bacterial wilt disease incited by Ralstonia solanacearum occurred in seven farms in six counties of Florida (Norman et al., 2018). This is a newly discovered disease causing significant damage to blueberries. The pathogen is easily spread in water, soil, or through infected plant materials. Propagation through in vitro culture has been considered the most effective method for a rapid increase of disease-free propagules on a year-round basis (Chen and Henny, 2008; Murashige, 1974).

Blueberries have been micropropagated via shoot culture (Fan et al., 2017; Frett and Smagula, 1983; Litwinczuk, 2013; Lyrene, 1980, 1981; Ruzic et al., 2012; Tetsumura et al., 2008) and through shoot organogenesis (Billings et al., 1988; Callow et al., 1989; Cao and Hammerschlag, 2000; Debnath, 2009; Liu et al., 2010; Rowland and Ogden, 1992). Shoot culture is the proliferation of existing meristems, whereas shoot organogenesis refers to regeneration from explants without preexisting meristems. The latter generally gives rise to a large number of shoots and is considered more efficient for plant multiplication. However, shoot organogenesis has only been established in a limited number of cultivars. Increasing evidence shows that protocols developed for regenerating blueberries are cultivar specific (Debnath, 2005, 2009; Liu et al., 2010; Meiners et al., 2007), implying that different cultivars may require different protocols for regeneration. Furthermore, shoot organogenesis is one of the regeneration pathways for genetic transformation (Song and Sink, 2004). Thus far, few cultivars have been genetically transformed (Gao et al., 2016; Song and Sink, 2004); the lack of reliable regeneration systems could be one of the limiting factors.

In addition, rooting of microcuttings is an important part of micropropagation. However, blueberry microcuttings are largely rooted ex vitro and little information is available about in vitro rooting of blueberries (Debnath, 2007; Litwinczuk, 2013). It is uncertain if rooted plantlets could have higher survival rates after being transplanted into soilless substrates.

The present study was intended to develop protocols for regeneration of four blueberry cultivars whose protocols for adventitious shoot production have been not reported. As part of the effort, two of the four cultivars were successfully regenerated through indirect shoot organogenesis. Microcuttings derived from adventitious shoots of a cultivar were evaluated for both in vitro and ex vitro rooting. Results suggest that the developed protocols could be used for micropropagation, genetic transformation or both of the two cultivars.

\section{Materials and Methods}

Plant materials and culture medium. In vitro cultured four cultivars, representing four of the five groups of blueberries, were used in this study: Bluejay ( $V$. corymbosum L.) which is a northern highbush cultivar; Pink Lemonade (a $V$. virgatum rabbiteye 
hybrid derivative); Sunshine Blue (V. corymbosum L.), a southern highbush cultivar; and Top Hat, a half-high derived from a cross between highbush and lowbush.

Woody plant medium (Lloyd and McCown, 1981) with vitamins (Product ID: L154; PhytoTechnology, Shawnee Mission, KS) was used as a basal medium. After adding 3\% sucrose and $0.8 \%$ agar, the medium $\mathrm{pH}$ was adjusted to 5.0 and autoclaved at $121^{\circ} \mathrm{C}$ for $20 \mathrm{~min}$. When medium temperature dropped to $\approx 50{ }^{\circ} \mathrm{C}$, filter-sterilized growth regulator solutions were added and mixed well before pouring into either glass baby food jars $(150 \mathrm{~mL})$ or petri dishes.

The in vitro cultures were initially established from stem explants cultured on WPM supplemented with 9.12 $\mu$ M 6-(4-hydroxy-3methylbut-2-enylamino) purine or $\mathrm{ZT}$ and $0.025 \mu \mathrm{M}$ IBA in baby food jars. After 10 weeks of culture in a culture room described in the following paragraphs, axillary shoots were used as sources of explants.

For producing callus explants, leaves derived from axillary shoots of 'Sunshine Blue' were cut to $\approx 16 \mathrm{~mm}^{2}$ pieces and cultured on WPM medium supplemented with $9.12 \mu \mathrm{M}$ $\mathrm{ZT}$ and $1.23 \mu \mathrm{M}$ IBA in petri dishes. After 2 weeks of culture, green callus formed along the edge of leaf explants. Three weeks later, calluses were excised and used as explants.

Evaluation of explants. Leaf explants $\approx 16 \mathrm{~mm}^{2}$, stem explants $\approx 5 \mathrm{~mm}$ long, and callus with a diameter $\approx 4 \mathrm{~mm}$ of 'Sunshine Blue' were cultured on petri dishes containing WPM medium supplemented with $9.12 \mu \mathrm{M}$ ZT and $0,1.23,2.46$, or $4.92 \mu \mathrm{M}$ IBA in a culture room. There were eight explants per dish and 10 dishes per treatment. Five weeks after culture initiation, explants with callus were recorded and callus formation frequencies were calculated. The callus-borne explants were then subcultured on fresh WPM medium containing the same concentrations of ZT and IBA in baby food jars. There were five explants per jar and 10 jars for each treatment. Another 5 weeks later, shoot numbers per explant were counted.

Evaluation of cultivars. Leaf explants $\approx 16 \mathrm{~mm}^{2}$ of 'Bluejay', 'Pink Lemonade', and 'Top Hat' were prepared from in vitrogrown plants and cultured in petri dishes containing WPM medium supplemented with $9.12 \mu \mathrm{M}$ ZT and $0,1.23,2.46$, or $4.92 \mu \mathrm{M}$ IBA in a culture room. Again, there were eight explants per dish and 10 dishes per treatment. Five weeks after culture, the explants with callus were recorded and were subcultured on fresh WPM medium containing the same ZT and IBA concentrations in baby food jars. There were five explants for each jar and 10 jars per treatment. Another 5 weeks later, shoot numbers per explant were counted.

In vitro rooting. Regenerated adventitious shoots ( $\approx 3 \mathrm{~cm}$ in height) of 'Sunshine Blue' were excised as microcuttings and rooted in WPM medium supplemented with 0, 2.46, 4.92 , or $9.84 \mu \mathrm{M}$ IBA in baby food jars. There were four microcuttings per jar and five jars for each treatment. Rooting percentage and root numbers were recorded after 10 weeks of culture.

In vitro culture conditions. All culture experiments designed for evaluating explants, cultivars, and in vitro rooting were maintained in a culture room under a $12-\mathrm{h}$ photoperiod provided by cool white fluorescent lamps with a photon flux density of 50 $\mu \mathrm{mol} \cdot \mathrm{m}^{-2} \cdot \mathrm{s}^{-1}$ and temperature of $25 \pm 2{ }^{\circ} \mathrm{C}$.

Ex vitro rooting and acclimatization. Microcuttings of 'Sunshine Blue' were dipped in deionized water, $4.92,9.84$, or $24.6 \mu \mathrm{M}$ IBA solutions for $10 \mathrm{~s}$. Dipped cuttings were rooted singly in cells of 72-plug trays filled with a peat-based substrate composed of $90 \%$ peat and $10 \%$ perlite with a $\mathrm{pH}$ of 5.0 . Meanwhile, plantlets derived from the in vitro rooting medium supplemented with $9.84 \mu \mathrm{M}$ IBA were transplanted into plug trays filled with the same substrate. The microcuttings were intermittently misted at $10 \mathrm{~s}$ per $30 \mathrm{~min}$ with light intensity of 100 $\mu \mathrm{mol} \cdot \mathrm{m}^{-2} \cdot \mathrm{s}^{-1}$ for $10 \mathrm{~d}$. After $1 \mathrm{month}$, plug trays were moved to a shaded greenhouse under a light intensity of $350 \mu \mathrm{mol} \cdot \mathrm{m}^{-2} \cdot \mathrm{s}^{-1}$ and fertigated with nitrogen at $100 \mathrm{mg} \cdot \mathrm{L}^{-1}$ every 2 weeks. Survival rate and root numbers per cutting were recorded 1 month later.

Experimental design and statistical analysis. All experiments were arranged as a completely randomized design. Each culture vessel (petri dish or glass baby food jar) was considered an experimental unit for in vitro culture. For ex vitro rooting, six cell plugs were considered an experimental unit, and each was repeated five times. Collected data were subjected to ANOVA using SPSS 13.0 for Windows (SPSS, Chicago, IL). When significant differences $(P<0.05)$ occurred, means were separated using Duncan's multiple range test at $P<0.05$ level.

\section{Results}

Explant effects. Callus (Fig. 1A), leaf, and stem explants were evaluated on WPM medium devoid of growth regulators or containing $9.12 \mu \mathrm{M} \mathrm{ZT}$ with three concentrations of IBA, respectively. Leaf and stem explants did not produce calluses, and callus explants
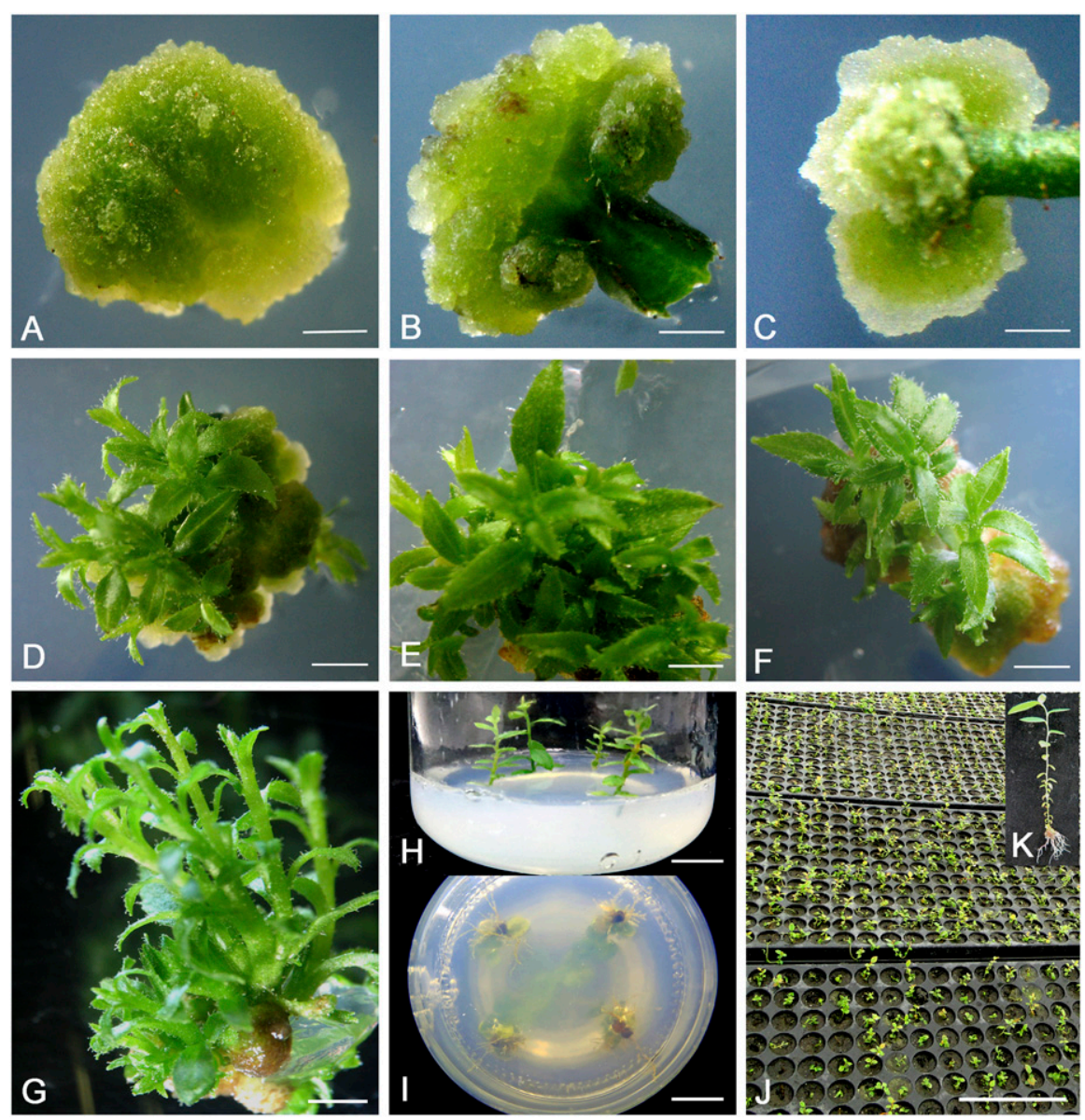

Fig. 1. Regeneration of Vaccinium corymbosum L. 'Sunshine Blue' through indirect shoot organogenesis and its rooting and acclimatization. Callus $(\mathbf{A})$, leaf $(\mathbf{B})$, and stem $(\mathbf{C})$ explants cultured on WPM medium supplemented with $9.12 \mu \mathrm{M}$ ZT and $2.46 \mu \mathrm{M}$ IBA, and callus occurred from one end of both leaf (B) and stem (C) explants. Adventitious shoots were formed from callus (D), leaf (E), and stem (F) explants. Multiple adventitious shoots produced from leaf explants (G) were excised to produce microcuttings which were rooted WPM medium supplemented with $9.84 \mu \mathrm{M} \mathrm{IBA}$ (H and I). Microcuttings dipped in a $9.84 \mu \mathrm{M}$ IBA solution also rooted ex vitro in a peat-based medium $(\mathbf{J})$, and abundant hair roots were produced 1 month after rooting $(\mathbf{K})$. All bars are equal to 2 mm except $\mathrm{H}$, $\mathrm{I}$, and $\mathrm{J}$ that are equal to $1 \mathrm{~cm}$. IBA = indole-3-butyric acid; WPM = woody plant medium; $Z \mathrm{~T}=$ zeatin. 
turned to brown when cultured on the medium devoid of growth regulators. However, callus formed on one end of both leaf and stem explants 2 weeks after culture, and callus mass quickly increased 3 weeks later (Fig. 1B and C). Callus formation frequencies were lower for both leaf and stem explants induced by $9.12 \mu \mathrm{M}$ ZT only but the frequencies greatly increased with the addition of IBA (Table 1). One week after subculture, adventitious shoots appeared (Fig. 1D, E, and F). Mean numbers of adventitious shoots per leaf explant increased significantly from 1.5 with no IBA to 4.51 with $2.46 \mu \mathrm{M}$ IBA, then decreased to 3.15 at the highest of concentration of IBA (Table 1). Stem explants responded to IBA addition more dramatically as number of adventitious shoots was only 0.93 without IBA and innumbers then gradually decreased at IBA concentrations of $2.46-4.92 \mu \mathrm{M}$. Adventitious shoot induction from callus explants followed the same trend as leaf explants but the mean numbers of shoots were lower than both leaf and stem explants. In general, adventitious shoots induced from leaf explants (Fig. 1E) were larger with more leaves compared with those induced from either callus (Fig. 1D) or stem explants (Fig. 1F).

Cultivar differences. Leaf explants of three cultivars cultured on the same medium exhibited similar responses as 'Sunshine Blue' in callus induction. No calluses were induced from the three cultivars when leaf explants were cultured on the medium without growth regulators. Callus formation frequencies across cultivars ranged from $20.44 \%$ to $56.57 \%$ in medium with ZT only (Table 2). Addition of IBA significantly increased callus formation frequencies, up to $90 \%$ for 'Bluejay' with $2.46 \mu \mathrm{M}$ IBA, $97.42 \%$ for 'Pink Lemonade' with IBA at $2.46 \mu \mathrm{M}$, creased to 4.27 with $1.23 \mu \mathrm{M}$ IBA. Shoot

and $96.19 \%$ for 'Tap Hat' with $1.23 \mu \mathrm{M}$ IBA. Induced callus from 'Bluejay' and 'Pink Lemonade', however, was less abundant than 'Top Hat' 5 weeks after the initial culture. As a result, adventitious shoot occurrence differed greatly among the cultivars. Shoot numbers of 'Bluejay' were lowest, less than 0.25 per explant. The mean number of adventitious shoots for 'Pink Lemonade' was close to one per explant induced by ZT only. With increasing concentration of IBA, however, shoot numbers decreased. Only 'Top Hat' responded positively to adventitious shoot induction. The shoot number was less than one per explant with ZT only, dramatically increased to 4.18 when supplemented with $1.23 \mu \mathrm{M}$ IBA, and then decreased to 3.20 and 2.72 , with IBA at 2.46 and $4.92 \mu \mathrm{M}$, respectively.

In vitro rooting. Adventitious shoots of 'Sunshine Blue' with a height $\approx 3.0 \mathrm{~cm}$ and 8-9 leaves (Fig. 1G) were cut at their base as microcuttings and rooted in WPM supplemented with IBA (Fig. 1H). Without the supplement of IBA, microcuttings failed to root; but IBA addition induced rooting (Fig. 1I). As IBA concentrations increased from 2.46 to $9.84 \mu \mathrm{M}$, rooting percentage increased from $52.78 \%$ to $91.67 \%$, and root numbers increased from 2.33 to 5.17 per microcutting (Table 3 ).

Ex vitro rooting. Microcuttings of 'Sunshine Blue' were able to root in a peat-based substrate regardless of water or IBA treatments (Table 4). The rooting percentages had no significant difference between microcuttings dipped in water and dipped in IBA at 4.92 or $9.84 \mu \mathrm{M} 10$ weeks after transplanting. However, the rooting percentage of microcutting dipped with $24.6 \mu \mathrm{M}$ IBA was significantly greater than control and those dipped in $4.92 \mu \mathrm{M}$ IBA. In addition, IBA treatments significantly increased root numbers per

Table 1. The number of adventitious shoots regenerated from leaf, stem, and callus explants of 'Sunshine Blue' cultured on woody plant medium supplemented with zeatin and IBA.

\begin{tabular}{|c|c|c|c|c|}
\hline Explant & Zeatin $(\mu \mathrm{M})$ & IBA $(\mu \mathrm{M})$ & Callus formation $(\%)^{z}$ & Shoot no. (per explant) $)^{y}$ \\
\hline \multirow[t]{5}{*}{ Leaf } & 0.00 & 0.00 & $0.00 \mathrm{c}^{\mathrm{x}}$ & $0.00 \mathrm{e}$ \\
\hline & 9.12 & 0.00 & $59.47 \pm 1.20 \mathrm{~b}$ & $1.50 \pm 0.56 \mathrm{c}$ \\
\hline & & 1.23 & $98.04 \pm 2.77 \mathrm{a}$ & $4.20 \pm 0.44 \mathrm{ab}$ \\
\hline & & 2.46 & $98.91 \pm 1.54 \mathrm{a}$ & $4.51 \pm 0.17 \mathrm{a}$ \\
\hline & & 4.92 & $97.17 \pm 4.00 \mathrm{a}$ & $3.15 \pm 0.08 b$ \\
\hline \multirow[t]{5}{*}{ Stem } & 0.00 & 0.00 & $0.00 \mathrm{c}$ & $0.00 \mathrm{e}$ \\
\hline & 9.12 & 0.00 & $61.07 \pm 3.89 \mathrm{~b}$ & $0.93 \pm 0.28 \mathrm{~cd}$ \\
\hline & & 1.23 & $99.85 \pm 5.25 \mathrm{a}$ & $4.27 \pm 1.14 \mathrm{a}$ \\
\hline & & 2.46 & $98.41 \pm 4.20 \mathrm{a}$ & $3.89 \pm 1.44 \mathrm{ab}$ \\
\hline & & 4.92 & $95.38 \pm 7.04 \mathrm{a}$ & $2.88 \pm 0.66 \mathrm{~b}$ \\
\hline \multirow[t]{5}{*}{ Callus } & 0.00 & 0.00 & $\mathrm{CTB}^{\mathrm{w}}$ & $0.00 \mathrm{e}$ \\
\hline & 9.12 & 0.00 & $\mathrm{ICM}^{\mathrm{v}}$ & $0.48 \pm 0.11 \mathrm{~d}$ \\
\hline & & 1.23 & $\mathrm{ICM}$ & $2.60 \pm 1.03 \mathrm{bc}$ \\
\hline & & 2.46 & ICM & $3.81 \pm 1.25 \mathrm{ab}$ \\
\hline & & 4.92 & $\mathrm{ICM}$ & $3.12 \pm 0.79 \mathrm{~b}$ \\
\hline
\end{tabular}

${ }^{\mathrm{z}}$ Callus formation frequency was the percentage of the number of explants with callus in relation to the numbers of explants cultured per petri dish. There were eight explants per dish and 10 dishes per treatment. ${ }^{\mathrm{y}}$ Mean shoot ( $\geq 2 \mathrm{~cm}$ long) numbers per explant. There were five explants per baby food jar and 10 jars per treatment.

${ }^{\mathrm{x}}$ Values in the last two columns are means $\pm \mathrm{SE}$, and different letters within a column indicate significant differences among the means based on Duncan's multiple range test at $P<0.05$ level with exception for callus under the callus formation.

${ }^{\mathrm{w}}$ Callus turned to brown.

$\mathrm{v}$ Increased callus mass.

IBA = indole-3-butyric acid. microcutting, up to 8.12 per cutting treated with $24.6 \mu \mathrm{M}$ IBA. Meanwhile, the mean survival rate and root numbers of in vitrorooted plantlets after transplanting into the peat-based substrate were similar to microcuttings dipped in $24.6 \mu \mathrm{M}$ IBA (data not shown). Plantlets grew well in a shaded greenhouse (Fig. 1J) and had abundant hair roots (Fig. 1K).

\section{Discussion}

Blueberry is a relatively new crop domesticated in the 20th century (Mainland, 2012). Over the last 50 years, increased numbers of new cultivars have been released (Brevis et al., 2008; Lobos and Hancock, 2015; Lyrene, 2008). The United States alone has more than 125 blueberry cultivars available on the market (Ehlenfeldt et al., 2010). The increased release of new cultivars coupled with increased production acreage requires more starting materials for commercial production (Fan et al., 2017; Tzanetakis et al., 2017).

Tissue culture has been used for blueberry propagation to speed up commercialization of new cultivars and to meet the demand for disease-free propagules for production. Methods for in vitro propagation through shoot culture (El-Shiekh et al., 1996; Frett and Smagula, 1983; Litwinczuk, 2013; Lyrene, 1980; Ruzic et al., 2012; Tetsumura et al., 2008) and via organogenesis (Billings et al., 1988; Callow et al., 1989; Cao and Hammerschlag, 2000; Debnath, 2009; Dweikat and Lyrene, 1988; Meiners et al., 2007; Rowland and Ogden, 1992) have been documented. A variety of factors including explants types, culture media, growth regulators, and cultivars can affect either shoot culture or organogenesis (Agarwal and Ranu, 2000). In general, newly expanded leaves are considered to be the preferred source of explant for regeneration (Cao and Hammerschlag, 2000; Debnath, 2009; Liu et al., 2010). Different culture media have been used for in vitro culture of blueberries, of which Anderson (Anderson, 1980), MS (Murashige and Skoog, 1962), WPM, and modified WPM (Tetsumura et al., 2008) are used for shoot culture, although for shoot organogenesis, WPM appears to be more widely used (Cao and Hammerschlag, 2000; Cappelletti and Mezzetti, 2016; Liu et al., 2010). Among growth regulators, $6-\gamma-\gamma$ (dimethylallylamino)-purine (2iP), N-phenylN'-1, 2, 3-thiadiazol-5-ylurea (TDZ) (Debnath, 2009), and $Z T$ along with $\alpha$-naphthalene acetic acid (NAA) and IBA have been used, but ZT appears to be more effective for shoot organogenesis and optimum concentration of ZT appears to be $9.12 \mu \mathrm{M}$ (Cappelletti and Mezzetti, 2016; Reed and AbdelnourEsquivel, 1991). Based on these previous reports, we selected WPM as a culture medium, $\mathrm{ZT}$ at $9.12 \mu \mathrm{M}$ in combination with different concentrations of IBA for the evaluation of four cultivars.

Cultivar is another variable in blueberry micropropagation. The present study showed 
Table 2. The number of adventitious shoots regenerated from leaf explants of 'Bluejay', 'Pink Lemonade', and 'Tip Hat' cultured on woody plant medium supplemented with zeatin and IBA.

\begin{tabular}{lcccc}
\hline Cultivar & Zeatin $(\mu \mathrm{M})$ & IBA $(\mu \mathrm{M})$ & Callus formation $(\%)^{\mathrm{z}}$ & Shoot no. (per explants) $^{\mathrm{y}}$ \\
\hline Bluejay & 0.00 & 0.00 & $0.00 \mathrm{f}^{\mathrm{x}}$ & $0.00 \mathrm{e}$ \\
& 9.12 & 0.00 & $20.44 \pm 5.50 \mathrm{e}$ & $0.17 \pm 0.02 \mathrm{de}$ \\
& & 1.23 & $39.94 \pm 7.66 \mathrm{~d}$ & $0.21 \pm 0.07 \mathrm{~d}$ \\
Pink Lemonade & 2.46 & $89.77 \pm 9.55 \mathrm{ab}$ & $0.24 \pm 0.07 \mathrm{~d}$ \\
& 0.00 & 4.92 & $84.64 \pm 2.73 \mathrm{~b}$ & $0.23 \pm 0.05 \mathrm{~d}$ \\
& 9.12 & 0.00 & $0.00 \mathrm{f}$ & $0.00 \mathrm{e}$ \\
& & 1.23 & $95.57 \pm 4.14 \mathrm{c}$ & $0.96 \pm 0.06 \mathrm{c}$ \\
Top Hat & 2.46 & $90.45 \pm 8.32 \mathrm{a}$ & $0.93 \pm 0.23 \mathrm{c}$ \\
& & 4.92 & $96.61 \pm 0.53 \mathrm{a}$ & $0.22 \pm 0.07 \mathrm{~d}$ \\
& 0.00 & 0.00 & $48.98 \pm 7.09 \mathrm{~cd}$ & $0.14 \pm 0.04 \mathrm{de}$ \\
& 9.12 & 1.23 & $96.19 \pm 3.30 \mathrm{a}$ & $0.00 \mathrm{e}$ \\
& & 2.46 & $88.89 \pm 3.95 \mathrm{ab}$ & $3.18 \pm 1.08 \mathrm{c}$ \\
& & 4.92 & $79.63 \pm 9.15 \mathrm{~b}$ & $2.72 \pm 0.45 \mathrm{~b}$ \\
\hline
\end{tabular}

${ }^{\mathrm{z}}$ Callus formation frequency was the percentage of the number of explants with callus in relation to the numbers of explants cultured per petri dish. There were eight explants per dish and 10 dishes per treatment. ${ }^{\mathrm{y}}$ Mean shoot ( $\geq 2 \mathrm{~cm}$ long) numbers per explant. There were five explants per baby food jar and 10 jars per treatment.

${ }^{\mathrm{x}}$ Values in the last two columns are means $\pm \mathrm{SE}$, and different letters within a column indicate significant differences among the means based on Duncan's multiple range test at $P<0.05$ level.

IBA $=$ indole-3-butyric acid.

Table 3. Effect of IBA concentrations on in vitro rooting of adventitious shoots and root numbers per shoot of 'Sunshine Blue' on woody plant medium. $^{\text {z }}$

\begin{tabular}{|c|c|c|}
\hline IBA $(\mu \mathrm{m})$ & $\begin{array}{c}\text { Root } \\
\text { formation }(\%)^{y}\end{array}$ & $\begin{array}{l}\text { Root no. } \\
\text { (per shoot) }\end{array}$ \\
\hline 0 & $0 \mathrm{c}^{\mathrm{x}}$ & $0 \mathrm{~d}$ \\
\hline 2.46 & $52.78 \pm 28.71 \mathrm{~b}$ & $2.33 \pm 1.13 \mathrm{c}$ \\
\hline 4.92 & $87.50 \pm 15.49 \mathrm{a}$ & $3.67 \pm 1.09 \mathrm{~b}$ \\
\hline 9.84 & $91.67 \pm 9.13 \mathrm{a}$ & $5.17 \pm 0.94 \mathrm{a}$ \\
\hline
\end{tabular}

${ }^{\mathrm{z}}$ There were four microcuttings per baby food jar, and five jars per treatment.

${ }^{\mathrm{y}}$ Values represent the percentage of microcuttings with roots ( $\geq 1 \mathrm{~cm}$ long) as compared with the number of cuttings being rooted per jar.

${ }^{x}$ Different letters within a column indicate significant differences among the means based on Duncan's multiple range test at $P<0.05$ level. $\mathrm{IBA}=$ indole-3-butyric acid.

Table 4. Effect of IBA concentrations on ex vitro rooting of microcuttings and root numbers per shoot of 'Sunshine Blue' in a peat-based substrate. ${ }^{\mathrm{z}}$

\begin{tabular}{llc}
\hline IBA $(\mu \mathrm{m})$ & $\begin{array}{l}\text { Survival } \\
\text { rate }(\%)\end{array}$ & $\begin{array}{c}\text { Number of } \\
\text { roots (per cutting) }\end{array}$ \\
\hline 0 & $86.67 \mathrm{~b}$ & $2.54 \mathrm{c}$ \\
4.92 & $86.67 \mathrm{~b}$ & $4.76 \mathrm{~b}$ \\
9.84 & $90.24 \mathrm{ab}$ & $7.84 \mathrm{a}$ \\
24.6 & $96.67 \mathrm{a}$ & $8.12 \mathrm{a}$ \\
\hline
\end{tabular}

${ }^{\mathrm{z}}$ Microcuttings were inserted into cells of plug trays filled with a peat-based substrate composed with $90 \%$ peat and $10 \%$ perlite based on volume, one cutting per cell; six plug cells as an experimental unit with five replications.

${ }^{y}$ Values represent the percentage of microcuttings survived or rooted ( $\geq 1 \mathrm{~cm}$ long) as compared with the number of cuttings being rooted.

${ }^{x}$ Different letters within a column indicate significant differences among the means based on Duncan's multiple range test at $P<0.05$ level.

IBA $=$ indole-3-butyric acid.

that cultivars vary significantly in shoot organogenesis. More than four adventitious shoots were regenerated per explant of 'Sunshine Blue' and 'Top Hat' when cultured on
WPM containing $9.12 \mu \mathrm{M}$ ZT, with either $1.23 \mu \mathrm{M}$ or $2.46 \mu \mathrm{M}$ IBA. However, adventitious shoots from 'Pink Lemonade' were less than one and 'Bluejay' were even lower (Tables 1 and 2). Cao and Hammerschlag (2000) showed that shoot numbers of blueberries 'Bluecrop', 'Duke', 'Georgiagem', 'Jersey', and 'Sierra' cultured on WPM with $20 \mu \mathrm{M}$ ZT were $0,8,9,1.5$, and 2 , respectively under a photosynthetic photon flux of 18 $\mu \mathrm{mol} \cdot \mathrm{m}^{-2} \cdot \mathrm{s}^{-1}$. In a study of four southern highbush cultivars in shoot organogenesis, Liu et al., (2010) found that mean shoot numbers regenerated from leaf explants cultured on WPM with $11.4 \mu \mathrm{M}$ ZT were 5.52 and 10.14 for blueberries 'Biloxi' and 'Emerald', but almost no shoots were regenerated for 'Jewel' and 'Jubilee'. When cultured with $4.54 \mu \mathrm{M}$ TDZ and $2.69 \mu \mathrm{M}$ NAA, shoots numbers were $1.44,1.38,13.24$, and 3.16 for 'Biloxi', 'Emerald', 'Jewel', and 'Jubilee', respectively. The cultivar differences may be related to their genetic backgrounds as most cultivars are polyploid hybrids (Ballington, 2009; Bian, 2012; Brevis et al., 2008; Lyrene et al., 2003). In the present study, 'Bluejay' is a hybrid resulting from a cross between Berkeley and Michigan highbush selection 241 (Bian, 2012), 'Pink Lemonade' is a hexaploid that is half $V$. virgatum (rabbiteye blueberry) and half synthetically derived hexaploidy (highbush-type germplasm) (Ehlenfeldt and Finn, 2007). 'Sunshine Blue' was selected from openpollinated 'Avonblue', whereas 'Avonblue' was selected from a cross between E-66 and Florida 1-3 (Brevis et al., 2008); and 'Tap Hat' is a hybrid selected from a cross between 'Michigan 19' and 'Berkeley' (Bian, 2012). Successful regeneration depends on coordinated actions between endogenous hormones and externally applied growth regulators (Hisano et al., 2016). Because of such diverse genetic backgrounds among cultivars, shoot endogenous cytokinin and auxin concentrations may vary greatly, and externally amended growth regulators, such as ZT and NAA in this study, may not be appropriate for shoot organogenesis of 'Pink Lemonade' and 'Bluejay'. Further research on developing methods for regenerating the two cultivars is warranted.

Limited information is available regarding in vitro rooting of blueberry microcuttings. Our results show that WPM supplemented 4.92 and $9.84 \mu \mathrm{M}$ IBA resulted in rooting percentages of $87.5 \%$ and $91.67 \%$ with root numbers 3.67 and 5.17 per microcutting, respectively (Table 3 ). On the other hand, ex vitro rooting appeared to be more effective than in vitro rooting (Table 4). In vitro-rooted plantlets, after transplanting to the peat-based substrate, were similar to the microcuttings dipped with $24.6 \mu \mathrm{M}$ IBA in root numbers and survival rates. Thus, in vitro rooting may not be a necessary step for rooting of microcuttings. The efficiency in ex vitro rooting may be related to the peatbased, acidic substrate ( $\mathrm{pH}$ 5.0). Low $\mathrm{pH}$ has been shown to be conducive for IBA action and thus enhances rooting of woody plant (Holt et al., 1998; Williams et al., 1985) and foliage plant cuttings (Chen et al., 2003). It was documented by Harbage and Stimart (1996) that as $\mathrm{pH}$ decreased from 7 to 5.5, lower concentrations of IBA were required to increase the root count of apple (Malus domestica) microcuttings. Another possibility could be because of the presence of ericoid mycorrhizal fungi in the substrate, which would enhance rooting. Root mass dramatically increased because of inoculation of an ericoid mycorrhizal fungus in Rhododendron fortunei, a relative of blueberry (Wei et al., 2016). The survival rate of plantlets was high, more than $90 \%$ under the greenhouse conditions, and plants grew vigorously and healthy. The use of the newly established protocols could lead to rapid commercial propagation of new cultivars of blueberry.

In conclusion, the present study developed appropriate protocols for regeneration of 'Sunshine Blue' and 'Top Hat' through indirect shoot organogenesis. Leaf explants can be cultured on WPM medium supplemented with $9.12 \mu \mathrm{M} \mathrm{ZT}$, with either $1.23 \mu \mathrm{M}$ or $2.46 \mu \mathrm{M}$ IBA for 'Sunshine Blue' or 9.12 $\mu \mathrm{M}$ ZT and $1.23 \mu \mathrm{M}$ IBA for 'Top Hat'. Five weeks after culture, explants with callus should be subcultured on the same fresh medium for inducing adventurous shoots. Microcuttings derived from adventitious shoots should be dipped in a $9.84 \mu \mathrm{M}$ IBA solution and rooted in a peat-based substrate in a shaded greenhouse. As far as is known, this is the first report of successful regeneration of 'Sunshine Blue' and 'Top Hat'. The established protocols are reliable and have been used to regenerate plants for blueberry production experiments in our laboratory during the last 3 years. The protocols could also be used for propagating a large number of liners for commercial production, for blueberry cultivar improvement or both through genetic transformation. 


\section{Literature Cited}

Agarwal, P.K. and R.S. Ranu. 2000. Regeneration of plantlets from leaf and petiole explants of Pelargonium hortorum. In Vitro Cell. Dev. Biol. Plant 36:392-397.

Anderson, W.C. 1980. Tissue culture propagation of red and black raspberries, Rubus idaeus and R. occidentalis. Acta Hort. 112:13-20.

Ballington, J.R. 2009. The role of interspecific hybridization in blueberry improvement. Acta Hort. 810:49-60.

Basu, A., M. Rhone, and T.J. Lyons. 2010. Berries: Emerging impact on cardiovascular health. Nutr. Rev. 68:168-177.

Bian, Y. 2012. Genetic diversity and population structure of cultivated blueberries (Vaccinium section Cyanococcus spp.). North Carolina State Univ., Raleigh, NC. MS Thesis.

Billings, S.G., C.K. Chin, and G. Jelenkovic. 1988. Regeneration of blueberry plantlets from leaf segments. HortScience 23:763-766.

Brazelton, C. 2015. World blueberry statistics and global market analysis. U.S. Highbush Blueberry Council, Folsom, CA.

Brevis, P.A., N.V. Bassil, J.R. Ballington, and J.F. Hancock. 2008. Impact of wide hybridization on highbush blueberry breeding. J. Amer. Soc. Hort. Sci. 133:427-437.

Callow, P., K. Haghigh, M. Giroux, and J.F. Hancock. 1989. In vitro shoot regeneration on leaf tissue from micropropagated highbush blueberry. HortScience 24:372-375.

Cao, X. and F.A. Hammerschlag. 2000. Improved shoot organogenesis from leaf explants of highbush blueberry. HortScience 35:945-947.

Cappelletti, R. and B. Mezzetti. 2016. TDZ, 2iP and zeatin in blueberry (Vaccinium corymbosum L., 'Duke' in vitro proliferation and organogenesis. Acta Hort. 1117:321-324.

Caspersen, S., B. Svensson, T. Hakansson, C. Winter, S. Khalil, and H. Asp. 2016. Blueberry-soil interactions from an organic perspective. Scientia Hort. 208:78-91.

Chen, J. and R.J. Henny. 2008. Role of micropropagation in the development of ornamental foliage plant industry, p. 206-218. In: J.A. Teixeira da Silva (ed.). Floriculture, ornamental and plant biotechnology, Vol. V. Global Sci. Books, London, UK.

Chen, J., D.B. McConnell, C.A. Robinson, R.D Caldwell, and Y. Huang. 2003. Rooting foliage plant cuttings in compost-formulated substrates. HortTechnology 13:110-114.

Debnath, S.C. 2005. A two-step procedure for adventitious shoot regeneration from in vitroderived lingonberry leaves: Shoot induction with TDZ and shoot elongation using zeatin. HortScence 40:189-192.

Debnath, S.C. 2007. Propagation of Vaccinicum in vitro: A review. Intl. J. Fruit Sci. 6:47-71.

Debnath, S.C. 2009. A two-step procedure for adventitious shoot regeneration on excised leaves of lowbush blueberry. In Vitro Cell. Dev. Biol. Plant 45:122-128.

Dweikat, M. and P.M. Lyrene. 1988. Adventitious shoot production from leaves of blueberry cultured in vitro. HortScience 23:629.

Ehlenfeldt, M.K. and C.E. Finn. 2007. G-435 and ARS 96-138, pink-fruited blueberry selection. HortScience 42:172-173.
Ehlenfeldt, M.K., J.J. Polashock, A.W. Stretch, and M. Kramer. 2010. Ranking cultivated blueberry for mummy berry blight and fruit infection incidence using resampling and principal components analysis. HortScience 45:1205-1210.

El Shiekh, A., D.K. Wildung, J.J. Luby, K.L. Sargent, and P.E. Read. 1996. Long-term effects of propagation by tissue culture or softwood single-node cuttings on growth habit, yield, and berry weight of 'Northblue' blueberry. J. Amer. Soc. Hort. Sci. 121:339-342.

Fan, S., D. Jian, X. Wei, J. Chen, R.C. Beeson, Z. Zhou, and X. Wang. 2017. Micropropagation of blueberry 'Bluejay' and 'Pink Lemonade' through in vitro shoot culture. Scientia Hort. 226:277-284

Frett, J.J. and J.M. Smagula. 1983. In vitro shoot production of lowbush blueberry. Can. J. Plant Sci. 63:467-472.

Gao, X., A.E. Walworth, C. Mackie, and G. Song. 2016. Overexpression of blueberry FLOWERING LOCUS T is associated with changes in the expression of phytohormone-related genes in blueberry plants. Hort. Res. 3:16053.

Harbage, J.F. and D.P. Stimart. 1996. Effect of $\mathrm{pH}$ and $1 H$-indole-3-butyric acid (IBA) on rooting of apple microcuttings. J. Amer. Soc. Hort. Sci. 121:1049-1053.

Hisano, H., T. Matsuura, I.C. Mori, M. Yamane, and K. Sato. 2016. Endogenous hormone levels affect the regeneration ability of callus derived from different organs in barley. Plant Physiol. Biochem. 99:66-72.

Holt, T.A., B.K. Maynard, and W.A. Johnson. 1998. Low pH enhances rooting of stem cuttings of Rhododendron in subirrigation. $\mathrm{J}$ Environ. Hort. 16:4-7.

Litwinczuk, W. 2013. Micropropagation of Vaccinium sp. by in vitro axillary shoot proliferation, p. 63-76. In: M. Lambardi, E.A. Ozudogru, and S.M. Jain (eds.). Protocols for micropropagation of selected economically-important horticultural plants. Springer, New York, NY.

Liu, C., P. Callow, L.J. Rowland, J.F. Hancock, and G.Q. Song. 2010. Adventitious shoot regeneration from leaf explants of southern highbush blueberry cultivars. Plant Cell Tissue Organ Cult. 103:137-144.

Lloyd, G. and B.H. McCown. 1981. Commerciallyfeasible micropropagation of mountain laurel Kalmia latifolia by shoot tip culture. Proc. Intl. Plant Prop. Soc. 30:421-427.

Lobos, G.A. and J.F. Hancock. 2015. Breeding blueberries for a changing global environment: A review. Front. Plant Sci. 6:782

Lyrene, P.M. 1980. Micropropagation of rabbiteye blueberries. HortScience 15:80-81.

Lyrene, P.M. 1981. Juvenility and production of fast-rooting cuttings from blueberry shoot cultures. J. Amer. Soc. Hort. Sci. 106:396-398.

Lyrene, P.M. 2008. Breeding southern highbush blueberries. Plant Breed. Rev. 30:353-414.

Lyrene, P.M., N. Vorsa, and N.R. Ballingto. 2003. Polyploidy and sexual polyploidization in the genus Vaccinium. Euphytica 133:27-36.

Mainland, C.M. 2012. Frederick V. Coville and the history of North American highbush blueberry culture. Intl. J. Fruit Sci. 12:4-13.

Marino, S.R., J.G. Williamson, J.W. Olmstead, and P.F. Harmon. 2014. Vegetative growth of three southern highbush blueberry cultivars obtained from micropropagation and softwood cuttings in two Florida locations. HortScience 49:556-561.

Meiners, J., M. Schwab, and I. Szankowski. 2007. Efficient in vitro regeneration systems for Vaccinium species. Plant Cell Tissue Organ Cult. 89:169-176

Miller, S.A., E.K. Rawnsley, J. George, and N. Patel. 2004. A comparison of blueberry propagation techniques used in New Zealand. Acta Hort. 715:397-402.

Miller, M.G. and B. Shukitt-Hale. 2012. Berry fruit enhances beneficial signaling in the brain. $\mathrm{J}$. Agr. Food Chem. 60:5709-5715.

Murashige, T. 1974. Plant propagation through tissue culture. Annu. Rev. Plant Physiol. 25:135-166.

Murashige, T. and F. Skoog. 1962. A revised medium for rapid growth and bioassays with tobacco tissue cultures. Physiol. Plant. 15:473497.

Norman, D.J., A.M. Bocsanczy, P. Harmon, C.L. Harmon, and A. Khan. 2018. First report of bacterial wilt disease caused by Ralstonia solanacearum on blueberries (Vaccinium corymbosum) in Florida. Plant Dis. 102:438.

Reed, B.M. and A. Abdelnour-Esquivel. 1991. The use of zeatin to initiate in vitro cultures of Vaccinium species and cultivars. HortScience 26:1320-1322.

Rowland, L.J. and E.I. Ogden. 1992. Use of a cytokinin conjugate for efficient shoot regeneration from leaf sections of highbush blueberry. HortScience 27:1127-1129.

Ruzic, D., T. Vujovic, G. Libiakova, R. Cerovic, and A. Gajdosova. 2012. Micropropagation in vitro of highbush blueberry (Vaccinium corymbosum L.). J. Berry Res. 2:97-103.

Song, G.Q. and K.C. Sink. 2004. Agrobacterium tumefaciens-mediated transformation of blueberry (Vaccinium corymbosum L.). Plant Cell Rpt. 23:475-484.

Tetsumura, T., Y. Matsumoto, M. Sato, C. Honsho, K. Yamashita, H. Komatsu, Y. Sugimoto, and H. Kunitake. 2008. Evaluation of basal media for micropropagation of four blueberry cultivars. Scientia Hort. 119:72-74.

Tzanetakis, I.E., R.C. Gergerich, and R.R. Martin. 2017. National blueberry certification scheme in the United States. Acta Hort. 1180:221-224.

USDA (United States Department of Agriculture). 2013. Economics, statistics and market information system. 26 Feb. 2018. <http://usda.mannlib. cornell.edu/MannUsda/viewDocumentInfo.do? documentID $=1765>$.

Vendrame, S., C. Del Bo, S. Ciappellano, P. Riso, and D. Klimis-Zacas. 2016. Berry fruit consumpation and metabolic syndrome. Antioxidants 5:34.

Wei, X., J. Chen, C. Zhang, and D. Pan. 2016. A new Oidiodendron maius strain isolated from Rhododendron fortunei and its effects on nitrogen uptake and plant growth. Front. Microbiol. 7:1327.

Whyte, A.R. and C.M. Williams. 2015. Effects of a single dose of a flavonoid-rich blueberry drink on memory in 8 to $10 \mathrm{y}$ old children. Nutrition 31:531-534.

Williams, R.R., A.M. Taji, and J.A. Bolton. 1985. Specificity and interaction among auxins, light, and $\mathrm{pH}$ in rooting of Australian woody species in vitro. HortScience 20:1052-1053. 